\title{
The Effect of the Chartered Accountant's Work on the Sustainability of the Lebanese Companies
}

\author{
Riad Makdissi' ${ }^{1}$, Anita Nehme², Mira Khawaja1 \\ ${ }^{1}$ Faculty of Economics and Business Administration, Lebanese University, Tripoli, Lebanon \\ ${ }^{2}$ Business Management and Administration Department, University of Balamand, Koura, Lebanon \\ Email: riad.makdissi@ul.edu.lb, anita.nehme@balamand.edu.lb, miraykhawaja@gmail.com
}

How to cite this paper: Makdissi, R., Nehme, A., \& Khawaja, M. (2020). The Effect of the Chartered Accountant's Work on the Sustainability of the Lebanese Companies. Open Journal of Accounting, 9, 15-29.

https://doi.org/10.4236/ojacct.2020.92002

Received: February 8, 2020

Accepted: March 17, 2020

Published: March 20, 2020

Copyright $\odot 2020$ by author(s) and Scientific Research Publishing Inc. This work is licensed under the Creative Commons Attribution International License (CC BY 4.0).

http://creativecommons.org/licenses/by/4.0/

\begin{abstract}
This article has been written with the aim of seeing the impact of the chartered accountant on the sustainability of Lebanese companies. In order to respond to this problem, we have presented a general vision of chartered accountants and the importance of their intervention in a company. Then we conducted interviews with fifty chartered accountants with large experience in different regions of the Lebanese territory in order to highlight the different missions they carried out in the Lebanese companies, their role in business continuity and development, how they faced their companies' challenges, what added values they offered to them, which then led us to summarize the tasks chartered accountants saw necessary for the continuity of the companies. We also have visited twelve accounting firms and see the different stages of the accounts' auditing. A questionnaire was prepared in order to collect all needed information. We distributed it to one hundred thirty companies in different regions with the aim of seeing the role played by the chartered accountants, the missions they carried out, the essential tasks to the companies' sustainability as well as other questions enriching our study which we have presented in this article.
\end{abstract}

\section{Keywords}

Chartered Accountant, Sustainability, Lebanon, Accounts Audit, Reporting

\section{Introduction}

The importance of accounting is spread over several levels. First of all, accounting is essential for a company in order to determine its expenses and revenues, which makes it possible to study its financial situation (Alkaswna, Al-Oqool, \& 
Bashayreh, 2014). Similarly, by evaluating the numbers, the company can make good decisions. In addition, with a well-structured accounting system the entity pays its taxes on time. Analyzing company reports can help determine the best time to buy inventory, start a new project and get a better view of the company's resources (Baldvinsdottir, Hagberg, Johansson, Jonäll, \& Marton, 2011).

The accounting profession includes several positions: accountant, chief accountant, chartered accountant, statutory auditors, etc., each having its importance and necessity for the company's sustainability and development.

In regards to the notion of the company's sustainability, it is based on the company's ability to continue its activities at the long-term level. Several indicators lead to the company's sustainability (Vlasova, Pimenova, Kuzmina, \& Morozova, 2016).

Olivier Lecerf considers that profit is not the only objective of the company but an indispensable factor for its continuity and the best measure of its success (Lecerf, 1991). According to Bloch and Nabat, innovation, transformation and strategy within the company are indicators that will help to ensure its sustainability (Bloch \& Nabat, 2009). In addition, some researchers consider that the size of the company, its field of activity, as well the number of employees, have an impact on its sustainability (Avesani, 2020).

In our research we were interested in presenting the profession of the Chartered Accountant and its impact on the sustainability of Lebanese companies. There are about 2000 chartered accountants in Lebanon, but the profession is practiced by only 1200 . A bookkeeper such as a chartered accountant can carry out multiple missions at various levels, and can be considered as one of the companies' indispensable partners (Asgary \& Maccari, 2019).

The Chartered Accountant is a professional accountant whose role is not limited to keeping the company's accounts and certifying them, but is also a true partner for the company who will provide advice in many areas that can help its continuity and its development (Grebe, 2016).

The purpose of this research can be summarized by searching for answers to the following problem:

"How can a chartered accountant ensure the company's sustainability?"

In order to approach Chartered Accountants' place in Lebanese companies and their importance for the company's continuity and development, we wanted to deepen our study by choosing them as a research subject. We will highlight the traditional path to becoming a chartered accountant, the reasons for calling, the importance of audit reporting, assigned tasks, actions and contribution for a sustainable business, auditing mission stages and finally roles and responsibilities of auditing firms.

\section{Literature Review}

According to Cyril Degrilart, Thomas Mehani, Driss Cherkaoui, "The chartered accountant is considered as the general practitioner of a company... He is the only professional mandated to be able to keep, monitor and stop the accounting, 
to be able to review it, assess it and finally attest its regularity and sincerity" (Degrilart, Mehani, \& Cherkaoui, 2015).

According to Manon Giraud, "Calling in a chartered accountant from the very beginning of a start-up project can be decisive in ensuring the development and sustainability of the company: he assists the project owner in drawing up a business plan and choosing the company's legal and tax status. He also assists in the search for and preparation of a financing file. In the case of the structures' acquisition, he may be asked to audit the new entity in order to guide any decisions that may be taken." (Giraud, 2019).

In general, the bookkeeper is responsible for establishing business accounts with the aim of presenting all the tax returns to the Government. He stands by the leaders to guide and advise them in different areas. Accounting is not his only field of activity. He can also accompany the company through all its phases (creation, development, acquisition and even at the stage of liquidation). In addition, when a company wants to carry out a new project, the chartered accountant must prepare a file containing a detailed study of this project, which will obviously help the entrepreneur to make the right decisions (Bouwer \& Schauten, 2019).

In Lebanon, chartered accountants are members of the Order of Chartered Accountants founded in 1995.

\subsection{The Traditional Path to Becoming a Chartered Accountant}

To become a Chartered Accountant in Lebanon, it is necessary to obtain the Higher Diploma in Accounting and Management at the Master's level $(\mathrm{Bac}+5)$, then it is essential to complete a paid internship of 3 years and pass the professional examination to obtain the Diploma of Chartered Accountant (DEC) equivalent to a $\mathrm{Bac}+8$.

\subsection{Engagement Letter}

The engagement letter is a contract between the Chartered Accountant and his client defining his missions and specifying the rights and obligations of each of the two parties. The code of ethics obliges both parties to respect this contract. Prior to writing this letter, the chartered accountant can determine the needs of the company, while the company manager can ask for specific missions (AICPA, 2019).

\subsection{Reasons for Calling in a Chartered Accountant}

According to Vincent Kolb, calling in a chartered accountant to share his service is not mandatory and is costly for the company, but the entrepreneur who does so has a better chance of getting through the first years of his entity's existence. A chartered accountant can intervene in the company not only in the field of accounting by processing, verifying, presenting and even auditing accounts, but also in different financial, administrative, operational and social sectors, becom- 
ing the entrepreneur's partner and confidant over time (Kolb, 2019).

Here are a few reasons why it is necessary to call in a chartered accountant (Orzolek, 2012).

The Chartered Accountant has an academic and professional background; this knowledge will help him to accompany the entrepreneur in all stages of the company. In addition, his knowledge is not limited to accounting but goes beyond it to financial, social, legal and tax aspects, allowing him to guide managers in making strategic decisions during companies' creation and development.

The Chartered Accountant helps to ensure compliance with laws and regulations. He is responsible for the consistency and plausibility of the annual accounts prepared. Due to his expertise, he also helps to prevent risks: detection, evaluation, prevention and support.

He can also offer the management tools to the owner/manager of the company; in addition, his presence brings more confidence to third parties.

\section{Research Methodology}

In order to answer our research question, we used a mixed method, combination of qualitative and quantitative methods for a better numerical measurement and in-depth exploration.

We have chosen the interview as a means of collecting the necessary information. In fact, the interview consists of verbally communicating with people who are involved in a specific study about a given subject. It is a means that offers qualitative information. We carried out interviews with fifty chartered accountants in different regions of the Lebanese territory, who are very well known for their skills. These accountants offered us their time and immense experience in order to give us answers to our research questions.

We were interested in interviewing chartered accountants in the Lebanese market in order to see the different missions they carry out in the Lebanese companies, their role in the continuity and development of the companies that appoint them, the advice they give to their clients and other information that enrich our research.

In addition, we have chosen the questionnaire as a means to collect the information we need and to obtain answers to the questions already asked. It is actually a quantitative method that allows us to validate and generalize the results. In fact, we have prepared a questionnaire, conducted with a number of business owners and managers belonging to different sectors of activity. One Hundred thirty owners/managers responded to our survey. We have chosen closed questions for our study, and then we made the questionnaire available for respondents on Google Forms.

We have formulated a questionnaire with 13 short, clear and precise questions, which helped us to collect information from companies in an easy way. We started by categorical questions in order to segment our respondents in spe- 
cified categories, we used also Likert scale questions, one of the most common ways to measure attitudes, opinions, and perceptions. Likert scale survey questions are defined by a large variety of response choices, generally from one extreme to another. We ended the questionnaire with one open-ended question to allow respondents to provide their own answers.

We also visited twelve accounting firms and saw the different stages of the accounts' auditing.

As shown in Figure 1, information was collected from 50 interviews with accountants, 12 site visits for auditing firms and 130 owners/managers who responded to our survey.

Samples were chosen with $90 \%$ confidence level and $10 \%$ margin of error, based on the below sample size formula:

Necessary Sample Size $=(Z \text {-score })^{2} \operatorname{StdDev}^{*}(1-\mathrm{StdDev}) /(\text { margin of error })^{2}$

According to Qualtrics, Z-score represents the confidence level; the value to be used is 1.645 for a $90 \%$ level of confidence. StdDev represents the standard deviation, the best value is 0.5 and the margin of error depends on how much errors we allow, for our survey $10 \%$ was considered as margin of error (Qualtrics, 2019).

With a population of 1200 active chartered accountant in Lebanon, the sample size should be 65 accountants. Due to limitations, 50 accountants accepted to make interviews with them.

For a large number of Lebanese companies, the sample size should be 68 companies. Due to our contacts we have reached a higher number but just 130 owners/managers accepted to take the survey, leading to a better research quality by increasing the confidence level to be $95 \%$ instead of $90 \%$ and decreasing the margin of error to be $9 \%$ instead of $10 \%$.

Concerning our site visits to auditing firms, with missing data and real numbers of active firms in the Lebanese market, the sample size should be 68 . Unfortunately, only 12 auditing firms accepted to welcome us in their premises.

\section{Analysis and Results Discussion}

After collecting answers, information, techniques and guidelines from our survey, meetings and sites' visits, we proceed by the classification and analysis in order to answer our research problem.

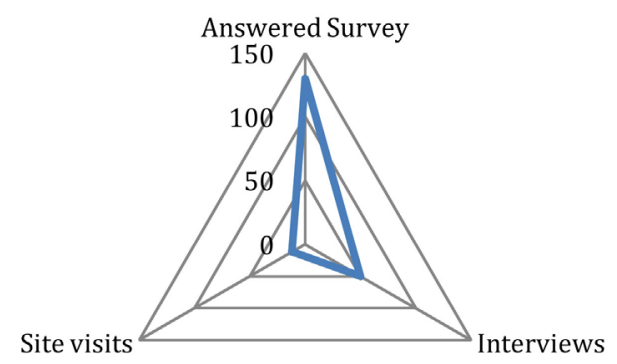

Figure 1. Research methodology. 
130 owners/managers of Lebanese companies from different fields and regions have answered to our survey, collected answers are as follow.

Figure 2, represents for how many years, the company has been calling a chartered accountant to intervene in the business. The majority goes to more than 5 years, with a percentage of $65 \%$. Complying with Lebanese law and regulations, yearly tax declaration, and benefiting from banks credit facilities pushed companies to call chartered accountants. The need for accounts auditing and financial records became a necessity for businesses looking for sustainability and development (Chaharmahali, Akbari, Rezaei, \& Mortazavian, 2013).

Figure 3 represents the reasons for calling auditors to intervene in the business. $35 \%$ of the enterprises call auditors just for government compliance. The external auditor can assist in discovering areas where the accounting practices are no longer in compliance with Government regulations and Ministry of Finance guidelines (Turpen \& Dyer, 2015). The auditor can additionally highlight where the compliance efforts may also be lacking. The second reason was the funding purpose, especially while applying for banks' credit facilities. 25\%, of our sample, were in need to call auditors in order to deliver audited financial reports to banks for loans approval. While $17 \%$ are interested in fraud prevention and declared that, it might be disagreeable to suppose that someone may want to be defrauding the company, so it will be better to be aware instead of wondering. The financial reports must reveal the complete truth for accountants and their independent review will protect the company from taking a significant risk (Florou, Morricone, \& Pope, 2019).

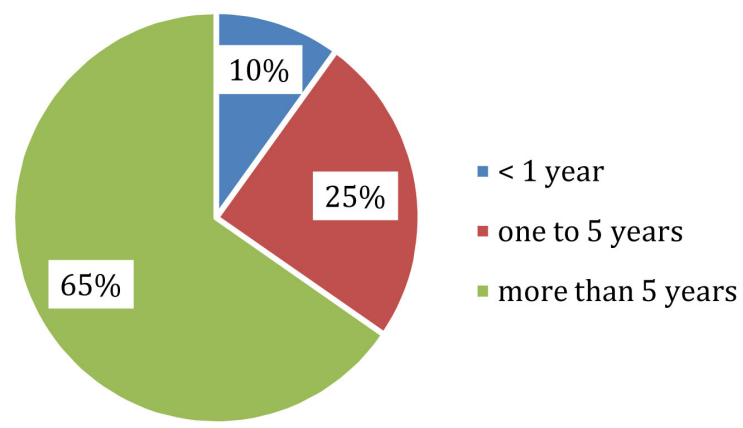

Figure 2. Number of years since calling a chartered accountant.

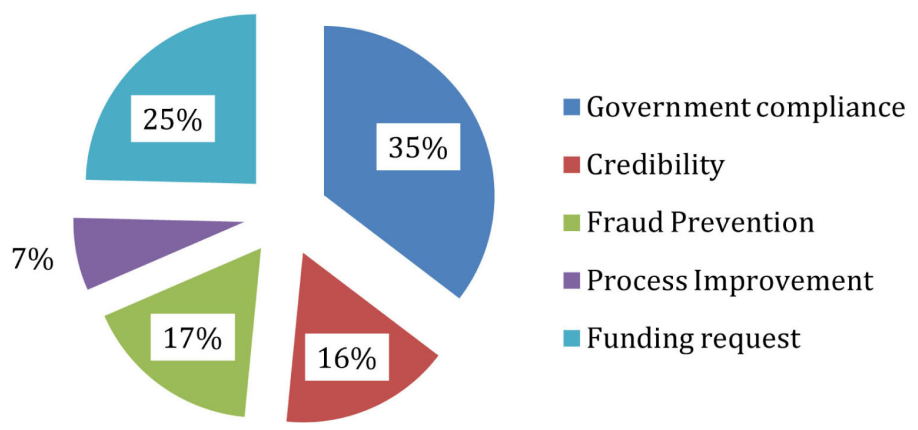

Figure 3. Reasons for calling auditors. 
Besides that, $16 \%$ are interested in business credibility towards stakeholders, and third parties. The financial reports can carry extra weight internally and externally if they are reviewed by an external auditor. Such audits provide common ground for the stakeholders to better evaluate the financial health of the corporation for family businesses, closely held corporations and non-profits (Endaya, 2018). External evaluations provide an objective overview into the organization's management practices for companies (Quick \& Henrizi, 2018).

The last reason for calling auditors was $7 \%$ for performance management. An external auditor can identify areas for performance management where we can strengthen our policies and procedures or simplify effective strategies to optimize them better. While these recommendations do not need to be implemented directly, understanding where waste and inefficiency originates would allow us to put in place a strategy to deal with the problems over time.

As shown in Figure 4, regular audits of financial statements are essential for the company's credibility (Funnell, Wade, \& Jupe, 2016). Audits will help with identifying and solving any underlying issues and provides higher trustworthiness for investors, shareholders, banks and tax officers (Al-Shaer \& Zaman, 2018). In addition, proper evaluations will give the owner/manager of the business a better financial security and more energy to plan ahead. According to our survey, most answers agreed that accounting and auditing can ensure the sustainability of their businesses. $77 \%$ answered that audit reporting helps ensuring consistency (37\% agree \& 40\% strongly agree); $72 \%$ agreed on company's decisions could be enhanced by reporting ( $40 \%$ agree \& $32 \%$ strongly agree); while $89 \%$ highlighted the importance in reporting by building trust with third parties and stakeholders ( $18 \%$ agree \& $71 \%$ strongly agree). As for risk management, $84 \%$ approved on having a better risk management by applying a good auditing ( $41 \%$ agree $\& 43 \%$ strongly agree).

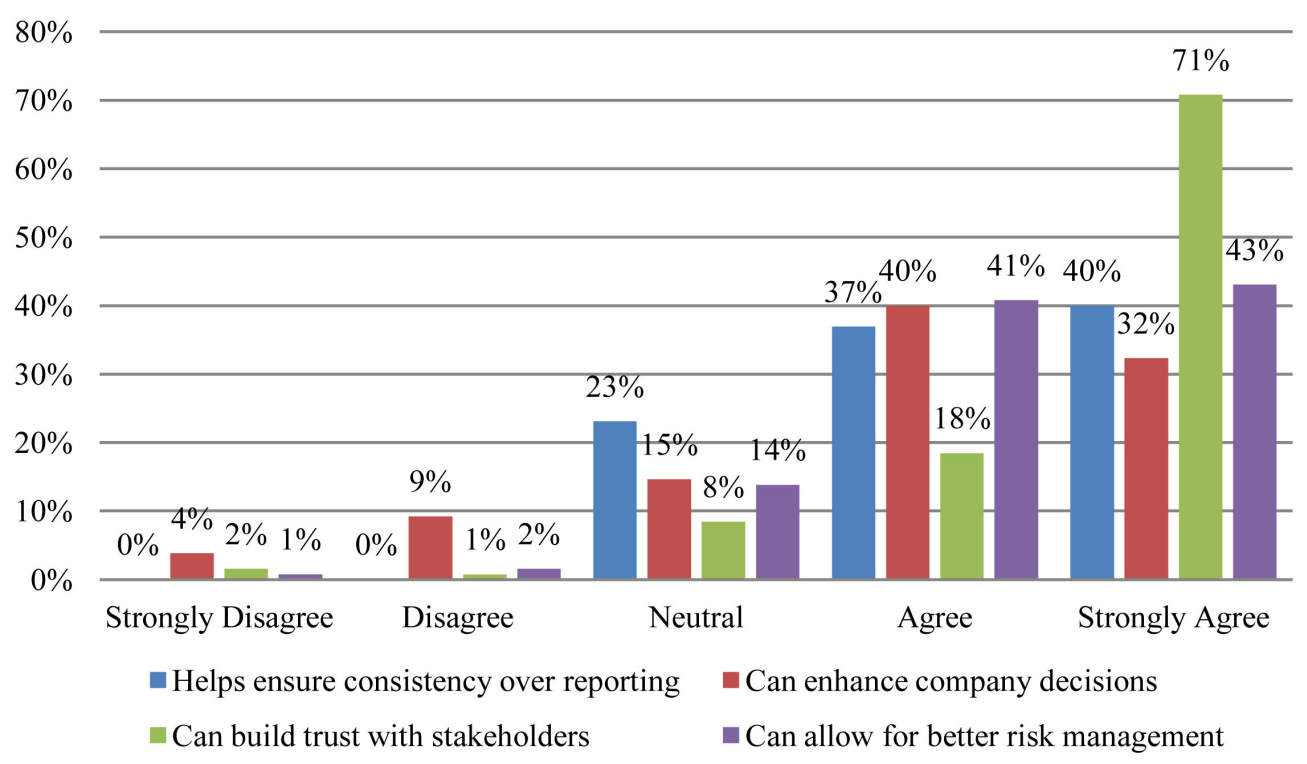

Figure 4. Importance of Audit Reporting. 
After interviewing qualified auditors, it was necessary to show their points of view regarding our research topic.

Based on Figure 5, tasks are many and diversified, 68\% of auditors were assigned for an essential step to comply with Lebanese regulations and ministry of finance guidelines, where 37\% asked for tax accounting; $31 \%$ asked for financial accounting, such as financial balance sheet and income statement needed for yearly declaration. Noting that some companies prepare themselves their financial reports but for the official declaration all reports must be audited. At this level, companies can assign a chartered accountant for financial accounting as we said before, or for auditing in order to verify all financial statements. $16 \%$ were asked for auditing services.

Chartered accountant tasks are not to be limited by simple accounting and auditing services, $10 \%$ asked for budget analyzing, going beyond numbers and ratio for a better view of the company's real situation while $6 \%$ asked for management accounting and helping managers taking the right decisions.

According to Figure 6, assigned tasks to Chartered accountants can support businesses for a better development and ensure a safely sustainability for them. Starting with business strategy where the responsibility of an accountant is to prepare a better strategic decision on business development and accounting assurance. The strategic approach is used to ensure that sustainability is integrated with management, accountability, vision, strategic planning, goals, leadership, objectives, and risk management agreements. The next stage is working on business operational activities as planning, budgeting, cost assessment and performance measurement. The implementation of management and accounting management may support to provide the required environmental, social, and financial evidence to support strategic thinking. Last stage to work on is reports, by preparing commercial, financial, sustainable and integrated reports, submit reviews and confirmations. Business sustainability needs to develop reports and disclosure strategy that provide a comprehensive view of the performance of the organization, including a reconciliation of methods to implementing the importance of the multilateral special representative; an external insurance and audit method lends credibility to the transparency of the enterprise and can also significantly improve it (Ngwakwe, 2011).

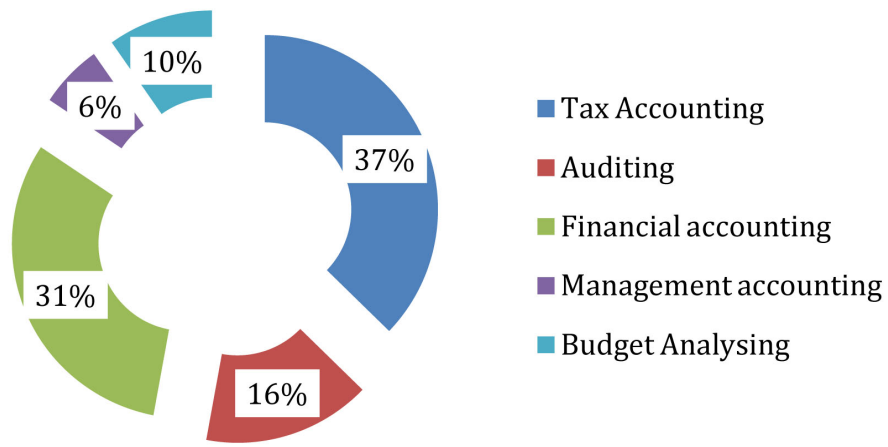

Figure 5. Assigned task to chartered accountant. 
As shown in Figure 7, accountants carry a significant role in business development (Shygun, 2019) and can contribute to its sustainability through:

- Detect and link main trends and implications to the strategy, operating model and reliability of the institution.

- Implementation through decision-making systems of important natural and social capital problems.

- Analyzing the financial advantages of overcoming environmental and social issues (e.g. cost reduction; generating income).

- Monitoring of internal policies and procedures to facilitate the measurement and control of what matters;

- Strategies and resources are connected to create value for stakeholders.

- Raising performance by reducing waste and controlling costs.

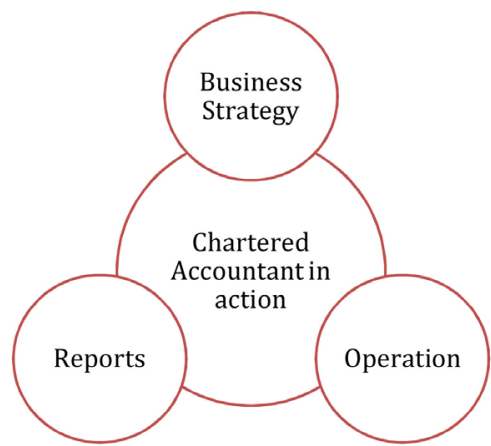

Figure 6. Chartered accountant in action for a sustainable business.

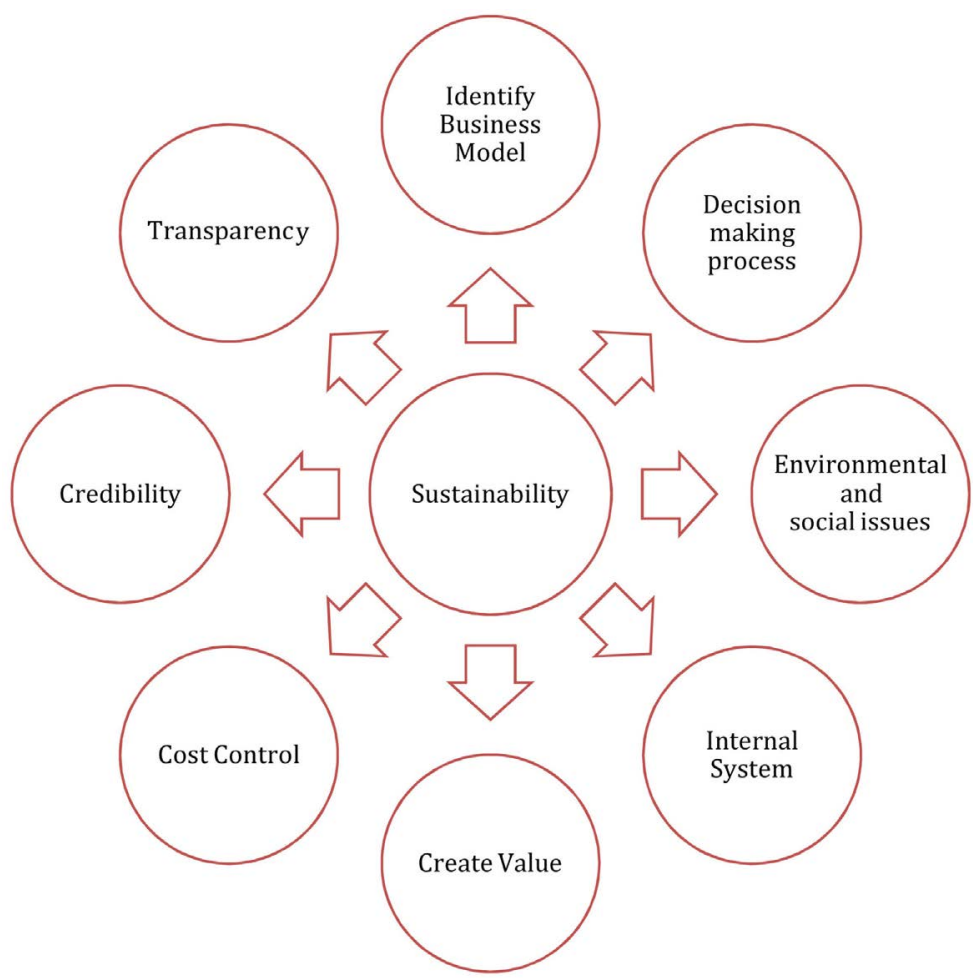

Figure 7. Eight ways accountants can contribute to sustainability. 
- Assuring credibility and information collection integrity by efficient control and management.

- Direct communication to promote transparency

The chartered accountant plays an important role in auditing companies' annual accounts before they are submitted to the Government in order to ensure the viability of the financial information and provide a true and fair view of the company. In some companies, especially in medium and large ones, there is an accounting department with a chief accountant, an accountant, etc. The latter prepares the company's balance sheet periodically, but before sending it to the Government, the chartered accountant audits the balance sheet and ensures that all the accounts comply with the law and the standards applied in Lebanon, and at the same time that its figures are real and in conformity.

We were interested to see how the chartered accountant audits the accounts. For this purpose, we have visited twelve accounting firms in order to see the accounts auditing mission carried out in Lebanon. It was possible to highlight the following steps to accomplish this mission.

According to Figure 8, external auditors pass through 7 key formalized stages when they may be auditing financial statements for clients (Langdon, 2016). At the first step, the auditor will work with the client to set up the scope of the audit, timescales, and assets. Responsibilities of the auditor and customer are normally outlined within an engagement letter. For the second step, the auditor needs to set up a database of client's historical past statistics to assess materiality of threat regarding misstatement of the financial papers. As for the third step, the auditor will perform a risk evaluation which questions: what may pass wrong? What's the probability of it going incorrect? What's the financial cost of the exposure?... After completing the first three steps, the auditor will carry out tests to check if key controls are running effectively, and are correctly designed. At the fifth step, the auditor exams if the account balances are accurate, and may additionally tests transactions and disclosures. For the 6th step, the audit is finalized and few techniques are carried out to make sure of validity. At this stage, final decisions may be made referring to the monetary assertion disclosures. The auditor will preserve meetings with senior management to discuss the findings. The last step is submitting the audit report.

As displayed in Figure 9, auditing firms, in order to serve their clients in an efficient and reliable way, must understand the business in study (type, activity,

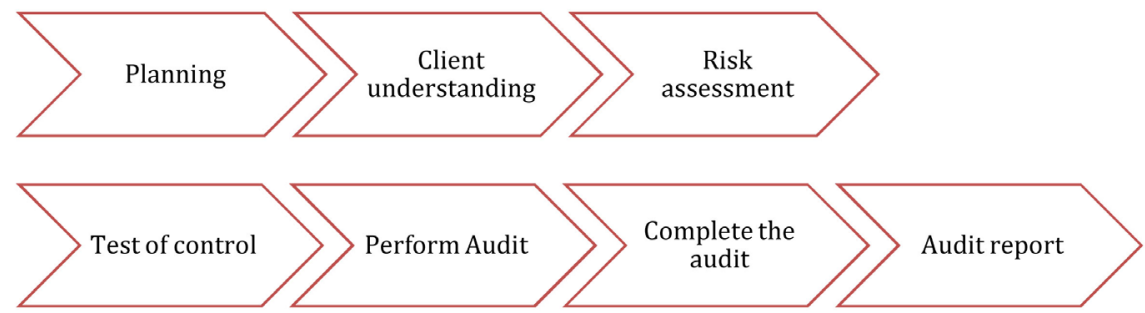

Figure 8. Auditing mission stages. 


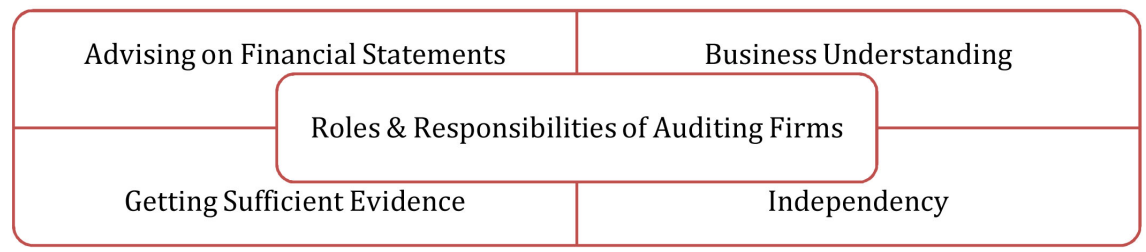

Figure 9. Roles \& responsibilities of auditing firms.

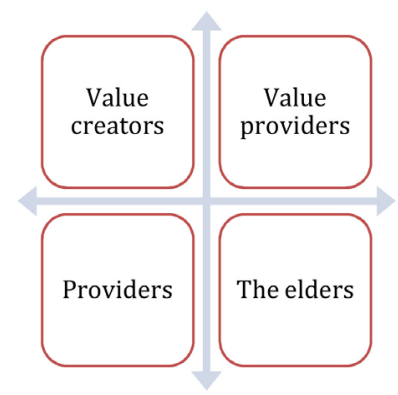

Figure 10. Key roles for professional accountants in sustainable business.

environment, operations, strategy, financials...) and get sufficient evidence to be able to advise in an independent way without any conflict of interest (Madison, 2019).

According to what we have mentioned before, we must highlight the collective role of the accounting profession in traditional and sustainable affairs. Accounting firms develop their methods and resources to allow companies to consider the risks and opportunities to sustainability. They promote main policies focused on developing sustainable development thinking and practices. Besides that, the qualified accountants, help in thinking development about sustainability and raise awareness about the importance of business success. They also establish an agreed corporate framework for sustainability reporting; prioritize business needs to develop business processes to ensure that complications and challenges related to sustainability are tackled in day-to-day management processes; review environmental information or sustainability information to see whether it is accurate, consistent and justifiable; identifying natural capital risks and opportunities.

Finally, it's time to identify the role of a professional accountant leading to a sustainable business as value creator, provider and protector (Makarenko \& Plastun, 2017).

As illustrated in Figure 10, chartered accountants, are identified as value creators, they take the lead in designing and executing strategies, policies, plans, processes and administrative actions that pave the way for the development of sustainable value. After that, they are knowns as providers of value, they provide management with financial data and guidance; make organizational decisions and execute the strategies to establish sustainable values; and prepare, track and develop support processes. The next step, acknowledged as keepers of value, will be to ensure that the sustainable value-creation plan is covered from strategic, 
operational, and financial risks, and to ensure compliance with good legislation, practices and standards for a smooth transition to the last stage, becoming reporters of value, to facilitate a transparent communication to stakeholder and ensure business sustainability (Busco, Grana, \& Izzo, 2018).

\section{Conclusions}

The chartered accountant is considered an indispensable partner for any company. This bookkeeper can intervene in the company during all its stages and across all fields.

According to the chartered accountants, different strategies and tasks can be carried out to help the company to remain sustainable and continue its activities (Sawers \& Whiting, 2020), some of which are listed below:

- Companies must submit their annual accounts and tax documents on time according to the period set by the Government.

- Organizations must comply with the standards set by the Government and the Ministry of Finance in order to avoid sanctions.

- Companies must ask the chartered accountant and the persons concerned to carry out a detailed analysis in case of starting a new project.

- Take into consideration all the points and information that the chartered accountant announces.

Several points must be respected and applied by the chartered accountant to improve his intervention in companies.

- The chartered accountant must comply with international and national standards and seeks to ensure that the company applies them in order to avoid sanctions.

- The chartered accountant must continuously update his knowledge.

- The chartered accountant must be innovative in order to attract new clients.

- Chartered accounting firms must work in their offices with all the technology that makes work easier and faster.

Chartered accountant may have quick access to information so that, with these new technologies, this professional can offer a wide range of services to the clients. With the newly created software, repetitive and daily tasks are carried out very quickly, allowing the chartered accountant to focus on more complex and important tasks.

With technological progress, all professions have undergone changes and mutations, so it is a must to face up to digital progress in the chartered accounting profession in order to remain on the market. Let's not forget the evolution of accounting standards that chartered accountants must be aware of in order to stay up to date. In fact, some studies show that within ten years or so, all companies, even very small and medium-sized enterprises, will not be able to survive without chartered accounting firms. In contrast, firms that have not been able to adapt to the digital age may disappear because of the digital transformation (Fettry, Anindita, Wikansari, \& Sunaryo, 2019). 
In Lebanon, the future of this profession is growing, especially with the new rules \& regulations issued by the Government in the last period. Thus, in the application of tax reforms, any company will need a chartered accountant who will help it in the accomplishment of its activities. Lebanese chartered accountants say that their work has increased in 2019 , as the individual companies are starting to seek their help more and more. The consultancy mission they offer is getting more needed and requested.

Chartered accountants are directly involved in this context to the implementation of sustainable development initiatives at company's level by:

- Using specialist agencies' materials synthesize various approaches to reframing the key position of professional accountants, offering a multidisciplinary perception of the accounting industry in the service economy.

- Using the corresponding gradation in business sustainable development: strategic, operational and reporting, defining the traditional functions and areas of responsibility of the chartered accountant in supporting decision-making.

The functional tasks of chartered accountants, the audit reporting, the accountant actions and positions are clearly correlated with company sustainable development shades.

At the structural level, chartered accountants express their power as creators of values serve as providers of sustainable development standards at the operational level and act as keepers and reporters at the reporting level.

The role of chartered accountants in sustainable development therefore needs to be updated in accordance with the financial and economic circumstances especially in Lebanon. After the revolution of October $17^{\text {th }} 2019$, businesses are facing critical financial and economic challenges, liquidity issues, high country instability, leading to failure and bankruptcy.

Simultaneously, professional competence mechanisms for chartered accountants necessitate yet more examination, as various groups of accountants are responsible for high-quality and reliable sustainable reporting, which is the subject for relevant data and objective support for sustainable development.

At the end, some limitations affected our research study and could be an opportunity for researchers to work on. Samples were selected with a $90 \%$ confidence level and 10\% margin of error. Adjusting these percentages (best result goes for a higher confidence level and for a lower margin of risk) could enhance the quality of the research results. As we said before, Lebanon is having a financial and economic crisis since October $17^{\text {th }} 2019$ and it will be important to update the role of chartered accountants in such case and review all procedures and mechanisms in order to help companies to survive where some of them came within 3 months of revolution to failure and closure.

\section{Conflicts of Interest}

The authors declare no conflicts of interest regarding the publication of this paper. 


\section{References}

AICPA (2019). General Principles for Engagements Performed in Accordance with Statements on Standards for Accounting and Review Services. In Codification of Statements on Standards for Accounting and Review Services (pp. 65-78). https://doi.org/10.1002/9781119630784.ch3

Alkaswna, R., Al-Oqool, M., \& Bashayreh, M. (2014). The Importance of the Accounting Information and the Role of the Scientific Accounting Research in Developing the Economic Development Service in the Developing Countries (Case Study Jordan). Research in Applied Economics, 6, 240-257. https://doi.org/10.5296/rae.v6i1.4699

Al-Shaer, H., \& Zaman, M. (2018). Credibility of Sustainability Reports: The Contribution of Audit Committees. Business Strategy and the Environment, 27, 973-986. https://doi.org/10.1002/bse.2046

Asgary, N., \& Maccari, E. (2019). Essentials of Bookkeeping. In N. H. Asgary, \& E. A. Maccari (Eds.), Entrepreneurship, Innovation and Sustainable Growth: Opportunities and Challenges. Abingdon-on-Thames: Taylor \& Francis. https://doi.org/10.4324/9780429261640-12

Avesani, M. (2020). Chap. 2. Sustainability, Sustainable Development, and Business Sustainability. In Life Cycle Sustainability Assessment for Decision-Making (pp. 21-38). Amsterdam: Elsevier. https://doi.org/10.1016/B978-0-12-818355-7.00002-6

Baldvinsdottir, G., Hagberg, A., Johansson, I.-L., Jonäll, K., \& Marton, J. (2011). Accounting Research and Trust: A Literature Review. Qualitative Research in Accounting \& Management, 8, 382-424.

Bloch, A., \& Nabat, E. (2009). Pérennité organisationnelle et transformation. Concilier l'inconciliable ? Revue Française de Gestion, 192, 113-126.

https://doi.org/10.3166/rfg.192.113-126

Bouwer, J., \& Schauten, M. (2019). Basics of Bookkeeping. London: Routledge. https://doi.org/10.4324/9781003022251

Busco, C., Grana, F., \& Izzo, M. F. (2018). Sustainable Development Goals and Integrated Reporting. Abingdon-on-Thames: Routledge. https://doi.org/10.4324/9780429027314

Chaharmahali, M., Akbari, J., Rezaei, H., \& Mortazavian, S. (2013). The Audit Confirmation Importance and Necessity. Advances in Environmental Biology, 7, 2914-2919.

Degrilart, C., Mehani, T., \& Cherkaoui, D. (2015). Réussir son diplôme d'expertise comptable. Levallois Perret, France: Studyrama.

Endaya, K. (2018). Coordination and Cooperation between Internal and External Auditors. Research Journal of Finance and Accounting, 5, 76-80.

Fettry, S., Anindita, T., Wikansari, R., \& Sunaryo, K. (2019). The Future of Accountancy Profession in the Digital Era. In A. G. Abdullah, I. Widiaty, \& C. U. Abdullah (Eds.), Global Competitiveness: Business Transformation in the Digital Era. Abingdon-on-Thames: Taylor \& Francis. https://doi.org/10.1201/9780429202629-2

Florou, A., Morricone, S., \& Pope, P. (2019). Proactive Financial Reporting Enforcement: Audit Fees and Financial Reporting Quality Effects. The Accounting Review, 95, 167-197. https://doi.org/10.2308/accr-52497

Funnell, W., Wade, M., \& Jupe, R. (2016). Stakeholder Perceptions of Performance Audit Credibility. Accounting and Business Research, 46, 601-619. https://doi.org/10.1080/00014788.2016.1157680

Giraud, M. (2019). L'expert-comptable, au coeur du parcours de l'entrepreneur. EntrePreneur nbr 8, SFC Group's quarterly newsletter.

https://www.groupesfc.fr/actualites-sfc/publications/91 lexpert-comptable-au-coeur-d 
u-parcours-de-lentrepreneur

Grebe, L. (2016). The Transformation of Chartered Accountants as Strategy Practitioners. 39th International Business Research Conference, Tokyo, Japan.

Kolb, V. (2019). 7 bonnes raisons de faire appel à un expert-comptable.

https://www.inextenso.fr/magazin/gerer-developper-mon-activite/faire-appel-expert-c omptable/

Langdon, R. (2016). Understanding the 7 Major Audit Phases. https://www.morganintl.com/blog/accounting-auditing/understanding-the-7-major-au dit-phases/

Lecerf, O. (1991). Au risque de gagner-Le métier de dirigeant (p. 252).

Madison, G. (2019). Roles \& Responsibilities of External Audit Firms. https://smallbusiness.chron.com/roles-responsibilities-external-audit-firms-73924.html

Makarenko, I., \& Plastun, A. (2017). The Role of Accounting in Sustainable Development. Accounting and Financial Control, 1, 4-12. https://doi.org/10.21511/afc.01(2).2017.01

Ngwakwe, C. (2011). Towards an Understanding of the Influence of Sustainability Culture on the Accounting Profession. International Journal of Sustainable Development and World Ecology, 18, 442-452. https://doi.org/10.1080/13504509.2011.589477

Orzolek, D. (2012). The Call for Accountability. Journal of Music Teacher Education, 22, 3-6. https://doi.org/10.1177/1057083712452260

Qualtrics (2019). Determining Sample Size: How to Ensure You Get the Correct Sample Size.

https://www.qualtrics.com/experience-management/research/determine-sample-size/

Quick, R., \& Henrizi, P. (2018). Experimental Evidence on External Auditor Reliance on the Internal Audit. Review of Managerial Science, 13, 1143-1176. https://doi.org/10.1007/s11846-018-0285-0

Sawers, D., \& Whiting, R. (2020). Chartered Accountants: Key Players in Business Succession Planning? SEAANZ Conference, Wellington, New Zealand.

Shygun, M. (2019). Conceptual Changes in Accounting under the Influence of Sustainable Business Development. Finansi Ukrä̈ni, 82-98.

Turpen, R., \& Dyer, H. (2015). Working with External Auditors: A Successful Relationship between Internal and External Auditors Depends on Collaboration and Open Communication to Achieve the Shared Goal of Effective Audit Service. Internal Auditor, $72,17$.

Vlasova, M., Pimenova, A., Kuzmina, S., \& Morozova, N. (2016). Tools for Company's Sustainable Economic Growth. Procedia Engineering, 165, 1118-1124. https://doi.org/10.1016/j.proeng.2016.11.828 